\title{
Impact of faecal DM excretion on faecal calcium losses in dogs eating complete moist and dry pet foods - food digestibility is a major determinant of calcium requirements
}

\author{
Ellen Kienzle ${ }^{1} *$ Thomas Brenten $^{2}$ and Britta Dobenecker ${ }^{1}$ \\ ${ }^{1}$ Department of Veterinary Sciences, Chair of Animal Nutrition and Dietetics, LMU München, Oberschleißheim, Germany \\ ${ }^{2}$ Mars Petcare Europe, Verden, Germany
}

(Received 7 November 2016 - Final revision received 27 January 2017 - Accepted 8 February 2017)

Journal of Nutritional Science (2017), vol. 6, e13, page 1 of 3

doi:10.1017/jns.2017.11

Abstract

The recommendations for the Ca supply for maintenance of dogs have been reduced by about $75 \%$ in the last decades. An important factor for Ca requirements is faecal Ca losses. In previous studies with experimental diets faecal Ca losses depended on Ca intake and on faecal DM excretion. A predictive equation for faecal Ca losses in $\mathrm{mg} / \mathrm{kg}$ body weight $(\mathrm{BW})$ developed in a fibre model is: faecal losses $=-33.8+(13.6 \mathrm{faecal} \mathrm{DM} \mathrm{excretion}(\mathrm{g} / \mathrm{kg} \mathrm{BW}))+$ $(0.78 \mathrm{Ca}$ intake $(\mathrm{mg} / \mathrm{kg} \mathrm{BW}))$. The present study aimed at testing this equation in pet food with material from trials carried out for other purposes. Digestion trials with twenty-five dry and fifteen moist foods (326 observations in total) were evaluated retrospectively. Faecal DM excretion and faecal $\mathrm{Ca}$ losses were significantly correlated $\left(r^{2} 0.86 ; P<0.001\right)$. There was a highly significant correlation $\left(r^{2} 0.87 ; P<0.001\right)$ between the experimentally determined faecal $\mathrm{Ca}$ excretion and the faecal $\mathrm{Ca}$ excretion predicted by the equation of Kienzle et al. The data from the previous fibre model study could be transferred to prepared moist and dry dog food. Faecal DM excretion has a considerable impact on faecal Ca losses in a practical feeding situation. In conclusion, Ca requirements for maintenance may vary with food DM intake and digestibility.

Keywords: Calcium requirements: DM digestibility: Faecal calcium losses: Dogs

Recommendations for Ca supply of adult dogs for maintenance have undergone enormous changes over the last decades. In 1974 the National Research Council (NRC) recommended a Ca supply of approximately $3.6 \mathrm{~g}$ for a $15 \mathrm{~kg} \mathrm{dog}{ }^{(1)}$. The German Society of Nutritional Physiology (GfE) recommended less than half of this amount ${ }^{(2)}$, and in 2006 the $\mathrm{NRC}$ reduced the recommended intake of a $15 \mathrm{~kg}$ dog to approximately $1 \mathrm{~g}$ $\mathrm{Ca}^{(3)}$, and the minimum requirements to half of this. The NRC discusses many uncertainties in the bioavailability of $\mathrm{Ca}$ in $\operatorname{dogs}{ }^{(3)}$. A recent meta-analysis ${ }^{(4)}$ plotted literature data on $\mathrm{Ca}$ intake against faecal $\mathrm{Ca}$ excretion in adult dogs in a modified Lukas test. The relationship between intake and faecal excretion showed a remarkable uniformity, a result which does not suggest a pronounced high variability of $\mathrm{Ca}$ availability. In trials with a low Ca intake of $\leq 30 \mathrm{mg} / \mathrm{kg}$ metabolic body weight (BW) there was, however, a high variation of faecal Ca excretion which ranged from 2 to $75 \mathrm{mg} / \mathrm{kg}$ metabolic BW. The data with very low faecal $\mathrm{Ca}$ excretion came exclusively from diets with meat and/or fat and/or cooked starch. These diets are likely to have a very high digestibility ${ }^{(3)}$. This suggests that digestibility of DM may affect faecal Ca losses. In a previous study with a fibre model Kienzle et al. ${ }^{(5)}$ showed that in diets with the same $\mathrm{Ca}$ intake faecal $\mathrm{Ca}$ excretion increased with faecal DM excretion, i.e. with a decrease in DM digestibility due to fibre addition. A predictive equation was established with the independent variables faecal DM excretion and Ca intake and

Abbreviations: BW, body weight; NRC, National Research Council.

* Corresponding author: Professor Dr E. Kienzle, email kienzle@tiph.vetmed.uni-muenchen.de 
Table 1. Crude nutrient content of diets (\% DM)

\begin{tabular}{llllll}
\hline & \multicolumn{1}{c}{ Protein } & \multicolumn{1}{c}{ Fat } & \multicolumn{1}{c}{ Fibre } & \multicolumn{1}{c}{ Ash } & N-free extract \\
\hline Mean & 28.7 & 19.5 & $2 \cdot 6$ & 8.7 & 40.5 \\
Range & $20.0-46.4$ & $8.9-41.5$ & $0.5-7.5$ & $6.1-15.0$ & $11.5-60.0$ \\
\hline
\end{tabular}

the dependent variable faecal Ca losses on a BW basis. The predictive equation for faecal $\mathrm{Ca}$ losses in $\mathrm{mg} / \mathrm{kg} \mathrm{BW}$ was: faecal losses $=-33.8+(13.6$ faecal DM excretion $(\mathrm{g} / \mathrm{kg} \mathrm{BW}))+$ (0.78 Ca intake $(\mathrm{mg} / \mathrm{kg} \mathrm{BW})$ ) (equation 1). In the present study we investigated whether this equation from a fibre model $^{(5)}$ would be suitable to predict faecal Ca losses in pet food from Ca intake and faecal DM excretion in a retrospective evaluation of an already existing dataset from a pet food digestion trial. The hypothesis was, that if this was true, then faecal $\mathrm{Ca}$ losses and consequently $\mathrm{Ca}$ requirements of dogs would vary with DM digestibility and food DM intake.

\section{Materials and methods}

Standard procedure digestion trials $(3 \mathrm{~d}$ dietary change to test diet, $7 \mathrm{~d}$ adaptation, $5 \mathrm{~d}$ trial, dogs separated for feeding, one meal per d, food intake measured daily, food allowance aimed to maintain BW according to historical data, dogs individually housed during $5 \mathrm{~d}$ trial for total faecal collection, water ad libitum, $\geq 2$ weeks break between trials) with twenty-five dry and fifteen moist complete and commercially produced pet foods (Table 1) were carried out. A total of forty dogs $(10-35 \mathrm{~kg}$ $\mathrm{BW}$, nineteen beagles and twenty-one foxhound-crossbreds, age $1.5-5$ years, thirty-three females, seven males, majority of animals intact, all products tested in both sexes, males in more trials than females, only one breed per trial) took part in the study. In total there were 326 single observations on $\mathrm{Ca}$ intake and faecal excretion (275 in beagles and forty-seven in foxhound-crossbreds). All procedures were approved by the Regierung von Oberbayern, the appropriate authority in Bavaria. For each trial the dogs were adapted to the food for a total of $10 \mathrm{~d}$. This was followed by total faecal collection for $5 \mathrm{~d}$. Faeces were lyophylised and ground. Ca was determined by flame photometry after wet digestion. Ca intake, faecal Ca and faecal DM excretion were calculated per $\mathrm{kg} B W$ to allow the application of the predictive equation of Kienzle et al. ${ }^{(5)}$ (equation 1). Linear regression analysis was carried out for $\mathrm{Ca}$ intake and faecal $\mathrm{Ca}$ excretion as well as between
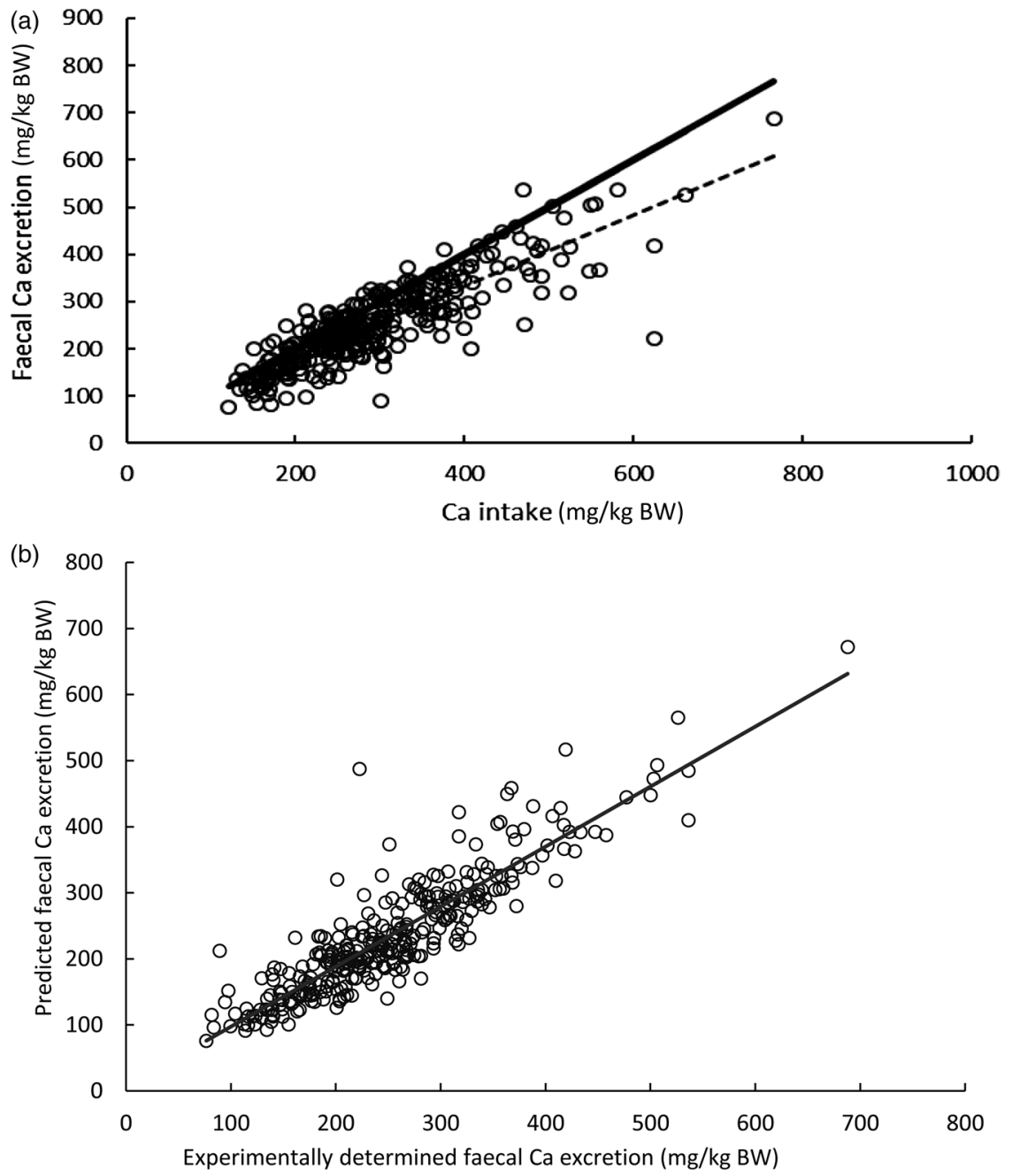

Fig. 1. (a) Relationship between calcium intake and faecal calcium excretion. ----, Regression line: $y=31 \cdot 66+0 \cdot 75 x$, sEM $45 \cdot 7 ; r^{2} 0 \cdot 741, n 326 ;-\longrightarrow, x=y$. (b) Relationship between experimentally determined and predicted faecal Ca excretion (by use of equation 1 ). $\longrightarrow$, Regression line: $y=6.47+0.91 x$, SEM $=33.6$; $r^{2}$ $0.80 ; n$ 326. BW, body weight. 
the experimentally determined faecal $\mathrm{Ca}$ excretion and the faecal $\mathrm{Ca}$ excretion as predicted by equation 1 . A multiple linear regression with the independent variables faecal DM excretion and $\mathrm{Ca}$ intake and the dependent variable faecal $\mathrm{Ca}$ losses was calculated with the pooled data from the fibre model $^{(5)}$ and the present study. All regressions were calculated using Sigmaplot 12.5 (Systat Software GmbH).

\section{Results}

$\mathrm{Ca}$ intake and faecal $\mathrm{Ca}$ losses correlated significantly $\left(r^{2} 0 \cdot 86\right.$; $P<0 \cdot 001$; Fig. 1(a)). Even though Ca intake was clearly above the current recommended intake in all experiments there was a considerable number of trials with negative apparent $\mathrm{Ca}$ digestibility (see dots above the $X=Y$ line in Fig. 1(a)). There was a highly significant correlation $\left(r^{2} 0 \cdot 87 ; P<0 \cdot 001\right)$ between the experimentally determined faecal $\mathrm{Ca}$ excretion and the faecal $\mathrm{Ca}$ excretion predicted by the equation of Kienzle et al. ${ }^{(5)}$ (equation 1) as shown in Fig. 1(b). The regression equation calculated from the pooled data of the present study and the investigation of Kienzle et al. ${ }^{(5)}$ between the independent variables faecal DM excretion $(\mathrm{g} / \mathrm{kg} \mathrm{BW})$ and $\mathrm{Ca}$ intake $(\mathrm{mg} / \mathrm{kg} \mathrm{BW})$ and the dependent variable faecal $\mathrm{Ca}$ losses $(\mathrm{mg} / \mathrm{kg} \mathrm{BW})$ was: faecal $\mathrm{Ca}$ excretion $=-9 \cdot 4+(0 \cdot 7 \mathrm{Ca}$ intake) $+(16 \cdot 8 \mathrm{DM}$ excretion) (equation 2$)$.

\section{Discussion and conclusions}

The results of the present study clearly show that the results of the previous study in a fibre model ${ }^{(5)}$ can be transferred to prepared pet food. Faecal DM excretion has a strong impact on faecal $\mathrm{Ca}$ excretion also in commercially produced pet food. The findings of the present study may help to explain discrepancies between studies on Ca metabolism in dogs due to the choice of diet. Renal and cutaneous Ca losses are very low in $\operatorname{dogs}{ }^{(2)}$. If these losses are not considered, a zero balance of $\mathrm{Ca}$ (i.e. maintenance of body $\mathrm{Ca}$ ) would be achieved if faecal losses equal intake. Assuming this is the case, equation 2 can be rearranged to calculate the amount of $\mathrm{Ca}$ intake required for zero $\mathrm{Ca}$ balance in relation to faecal DM excretion and model calculations can be carried out for varying DM intake and DM digestibility. For example, if a dog with $15 \mathrm{~kg} \mathrm{BW}$ eats $20 \mathrm{~g}$
$\mathrm{DM} / \mathrm{kg} \mathrm{BW}$ and the DM digestibility of the food is $75 \%$, a zero balance of $\mathrm{Ca}$ would be maintained at a $\mathrm{Ca}$ intake of $3.7 \mathrm{~g}$. This agrees excellently with the recommendation of the $1974 \mathrm{NRC}^{(1)}$. On the other hand, if the DM digestibility is $90 \%$ and DM intake $20 \mathrm{~g} / \mathrm{kg} \mathrm{BW}$, the amount of Ca which would then maintain body $\mathrm{Ca}$ in a $15 \mathrm{~kg}$ dog is only $1.2 \mathrm{~g}$, which is rather close to the recommended allowance of the $2006 \mathrm{NRC}^{(3)}$. These model calculations clearly show that DM digestibility and DM intake have to be considered for the recommendations for $\mathrm{Ca}$ allowance.

\section{Acknowledgements}

Digestion trials were funded by MARS.

E. K. was involved in the experimental design, i.e. was involved in the idea of testing the results of the fibre model study in prepared pet food. She carried out the statistics and wrote the manuscript. B. D. was involved in the experimental design, i.e. was involved in the idea of testing the results of the fibre model study in prepared pet foods. She carried out the digestion trials and collected the data. T. B. was involved in the study design, provision and control of the nutritional compliance of the trial diets. All authors were responsible for the final content of the manuscript.

T. B. is an employee of Royal Canin. There were no other conflicts of interest.

\section{References}

1. National Research Council (1974) Nutrient Requirements of Dogs. Washington, DC: National Academies Press.

2. Ausschuß für Bedarfsnormen der Gesellschaft für Ernährungsphysiologie (1989) Energie- und Näbrstoffbedarf: Nr. 5 Hunde (Energy and Nutrient Requirements: no 5 Dogs). Frankfurt: DLG Verlag.

3. National Research Council (2006) Nutrient Requirements of Dogs and Cats. Washington, DC: National Academies Press.

4. Mack JK, Alexander LG, Morris PJ et al. (2015) Demonstration of uniformity of calcium absorption in adult dogs and cats. J Anim Physiol Anim Nutr 99, 801-809.

5. Kienzle E, Dobenecker B, Wichert B et al. (2006) Effect of fecal water and dry matter excretion on fecal mineral excretion in dogs studied in a fiber model. J Nutr 136, 2001S-2003S. 